\title{
PERSONAL DEVELOPMENT - CHALLENGES AND OPPORTUNITIES FOR KNOWLEDGE SPILLOVERS IN ROMANIA
}

\author{
ZIRRA, D. \& MUNTEANU, A.C.
}

Abstract: In present day society, the central element of a sustainable human resources development is the efficiency level of knowledge transfer. Access to and transfer of knowledge quality is vital to the success of any kind of organisations. In the same time, knowledge needs to circulate freely at all levels of society. So, all the facts outlined before are fundamental prerequisites for increasing the economic performance, company management quality and competitiveness. In these conditions, given the amplitude of the changes brought about by globalisation and by expansion of the knowledge-based society, if we want to emerge the economic, social and environmental spillovers, it is necessary to built up a certain minimum threshold of dynamic and dynamical resources, including here the innovative education. For this purpose we need to provide flexible and updated life-long learning and training services, reconsider the significance of the components of human resources development, create organisational and cross-organisational, disciplinary and cross-disciplinary communication networks and to ensure an ongoing communication between employees and employers.

Key words: personal development process, transfer of learning, life-long learning, human resources development
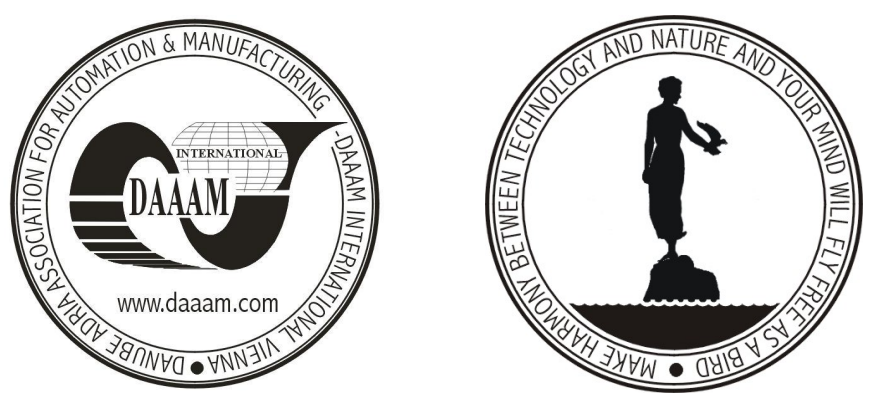

Authors' data: PhD. Ass. Prof. Zirra, D[aniela]*; Leading Researcher Munteanu, $\mathrm{A}$ [ndreea] C[lara]**,* Romanian-American University, 58th Lascăr Catargiu Boulevard, Sector 1, Bucharest, Romania, ** Romanian Academy Institute of National Economy Bucharest, 3rd Drumul Murgului. St., S33A Building, 52nd Apartment, 3rd District, Bucharest, Romania, daniela.zirra@gmail.com, acmunteanu@gmail.com

This Publication has to be referred as: Zirra, D. \& Munteanu, A.C. (2007). Personal development - challenges and opportunities for knowledge spillovers in Romania, Chapter 27 in DAAAM International Scientific Book 2007, B. Katalinic (Ed.), Published by DAAAM International, ISBN 3-901509-60-7, ISSN 1726-9687, Vienna, Austria

DOI: $10.2507 /$ daaam.scibook.2007.27 